\title{
NEWS
}

Nature 441, 678 (8 J une 2006) | doi: 10.1038/441678a; Published online 7 J une 2006

\section{Online methods share insider tricks}

http://www. nature.com/nature/journal/v441/n7094/full/441678a.html

Helen Pearson

Wiki-style website allows tinkering with lab protocols.

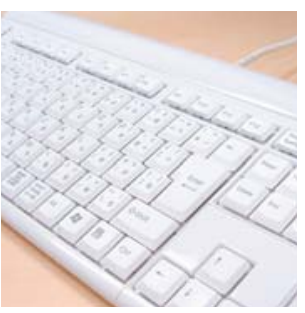

1. Replicating controversial lab results or tricky methods could become easier, thanks to a new breed of websites where scientists share and edit each other's laboratory techniques.

2. Laboratory protocols in biology and chemistry - the step-by-step guide to, say, separating proteins or splicing DNA fragments - are conventionally published in research papers or books of standard protocols. The instructions should allow another researcher to copy and confirm an experiment.

3. But scientists know that these recipes are seldom enough. Journals are cutting their methods sections to save money. And printed protocols lag behind rapidly evolving and increasingly sophisticated techniques, such as the nuclear transfer used in cloning.

4. Perhaps more importantly, it is the subtle variations - the deftness of touch, the type of mixing tube, and a dash of hocus-pocus - that distinguish a successful experiment from a flop. But such details often exist only as scrawled footnotes or collective laboratory wisdom. "The art of the science really is not present in many of these protocols," says geneticist Garry Nolan of Stanford University, California, who has put his protocols online. "They don't tell people what the voodoo is."

5. The websites could help share the voodoo. They are loosely based on the online encyclopaedia Wikipedia, which lets users edit each other's entries. Unlike the protocols already available online, the idea is to create a repository of experiments and the tricks needed to do them, and allow users to add their own.
6. One burgeoning site, OpenWetWare, was set up just over a year ago by students at the Massachusetts Institute of Technology. The Wikipedia-style site, featuring methods and other scientific resources, had around 30,000 users last month. One of the most popular protocols, used to measure the level of protein production in cells, now includes experimental data posted by users to let others know what to expect.

7. "You can't find this information anywhere else," says one of OpenWetWare's founders, Sriram Kosuri, a graduate student in synthetic biology. The site is particularly popular among researchers in synthetic biology, who want to create standard tools for engineering biological systems.

8. Two other competing sites are starting up. One, from the Cold Spring Harbor Laboratory Press, launched last week, and one, from the Nature Publishing Group, publisher of Nature, is due to launch in June. Both will feature commissioned protocols, which users will be able to comment on and add to. Unlike Wikipedia, comments will be screened before they are published and some of the material will be available only to subscribers.

9. Advocates say the sites have several advantages. They help busy lab heads deal with enquiries about their protocols. By removing some of the mystery from methods, they could help researchers iron out flaws, and perhaps verify controversial results. They might also raise the profile of methods, often glossed over as the means to the more exciting results. 
10. On the flip side, a laboratory worker could end up drowning in information. And the sites will be successful only if enough scientists embrace them. Researchers in competitive fields might hold back methods that they think give them an edge. "A lot of molecular biologists are not very comfortable on the Internet to begin with," says systems biologist Pamela Silver of Harvard Medical School, who uses OpenWetWare.
11. And even the sites' supporters admit that a written protocol still cannot compare to learning on the job from a lab veteran. "The very best way," says J ohn Inglis, executive director of the Cold Spring Harbor Laboratory Press, "is to sit beside someone who's doing it."

\section{Science key words}

リード Wiki-style : Wiki 形式の

Wiki とは、ウェブブラウザからページの作成・編集が誰に でもできるコンテンッサーバーのこと。Wikipedia は、この Wiki というツールを利用した百科事典。

リード lab protocols : 実験プロトコル 実験の手順および条件などについて明記した、実験のレシピ。

2. splicing DNA fragments : DNA 断片のスプライシング DNA の断片を切り貼りし、遺伝情報を組み込むこと。遺伝工学 などでよく使われる技術。スプライシングとは、直鎖状ポリマー から一部分を取り除き、残りの部分を結合すること。

3. nuclear transfer : 核移植

ここでは nuclear transplantation と同義で、核を取り除い
た細胞に別の（特に体細胞からの）核を導入すること。核の中 に含まれる遺伝情報が細胞のふるまいや運命を決定することか ら、クローン技術における重要なプロセスとなっている。

3. cloning : クローン化（クローニング）

ここでは、同一の遺伝情報をもつ細胞や個体を作ること。細胞 分子生物学では、特定の DNA 配列を増幅することもいう。

7. synthetic biology : 合成生物学

生物学とその他の科学技術を結びつけることにより、まったく新 しい生物的機能やシステムを生み出そうとする生物学の新分野。

10. systems biologist : システム生物学者 分子・細胞レベルの生命現象をシステムとして解析・記述しよ うとする、システム生物学の研究者。

\section{Words and phrases}

リード tinker with : 「細かく手を加える」「いじくり回す」

1. a new breed of ... : 「新しいタイプの …「新種の …」

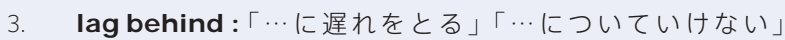
例: Sometimes the laws lag behind the times. (出典 :『最新ビジネ ス・技術実用英語辞典』日外アソシエーツ、1996 年)

4. deftness of touch : 「手先の器用さ」

4. a dash of .... : 「少量の 」

4. hocus-pocus : もともとは「呪文」「まじない」のことだが、 ここでは科学研究の話だから、「こつ」「秘訣」。

4. flop : 「大失敗」「失敗作」

4. voodoo : もともとブードゥ一教（魔術的宗教の一種）のことで、 そこで使われる「まじない」「呪術」という意味合いが一般化した もの。ここでは hocus-pocus の言いかえで、「こつ」「秘訣」の意味。

5. the idea is to ... : 「その目的 /意図/ねらいは…である」

6. burgeoning :「急成長している」「急速に発展している」。名 詞 burgeonは「新芽」のこと。

8. due to .... : 「…する予定になっている」「…することになって いる」。このほかにも「〜という理由で」という意味の due to も頻繁に用いられるが、その違いに注意。

8. commissioned : 「執筆依頼や委託、委嘱に基づいた」 例 : Most articles are commissioned, but proposals can be made to the Editor in advance of publication of the paper or well before the meeting is held. (出典 : Nature Physics, Guide To Authors)

9. iron out : もともとはアイロンをかけて、しわなどをとるこ
と。転じて「(不要なもの) を取り除く」「(問題点を) 解決する」 という意味になった。

9. verify : 科学に関する文章では、調査・研究・実験などによっ て、仮説・計算結果・実験結果などが正しいこと（現実に起こ ること）を「検証する」「確認する」という意味

例 : Experimentally verifying this prediction would be an interesting application of synthetic genenetworks.

(出典 : Nature Insight - Computational Biology 2003 - Engineered gene circuits)

9. raise the profile : 「知名度 $/$ 認知度 / 注目度を高める」。 profile は「プロフィール」「輪郭」「形状」という意味もあるが、 ここでは世間での「注目度」「目立ち具合」。

9. glossed over : 「うわべを飾る」「いい逃れる」「ごまかす」な どの意味。ここでは、注目を集める実験結果の陰で「目立たな い存在にさせられている」ということ。

10. On the flip side : 「その一方で」「その反面」「別の見方をす ると」。flip side とは「(コインなどの) 裏面」のことで、あ る事柄のもう一つの側面を意味する。

10. end up ....ing : 「最後には ‥になる」「…という状態こなってしまう」

10. embrace : 原意は「抱きしめる」だが、思想・学説・技術が 目的語になると、「採用する」などと訳す。

10. hold back : ここでは「秘密にする」。

10. give ... an edge : ここでの edge とは「強み」「優位性」な ので、「…に強みや優位性を与える」。

10. to begin with : 「何よりもまず」「第一に」

11. on the job : 「実際の仕事を通じて」「職務中に」 
Nature 441, 678 ( 8 J une 2006) | doi: 10.1038/441678a; Published online 7 J une 2006

\section{身内のみが知り得る秘訣をオンラインでシェアする方法}

http://www. nature.com/nature/journal/v441/n7094/full/441678a.html

ヘレン・ピアソン

ウィキ方式のウェブサイトで、他人の実験プロトコルにあれこれと手を加えられるようになった。

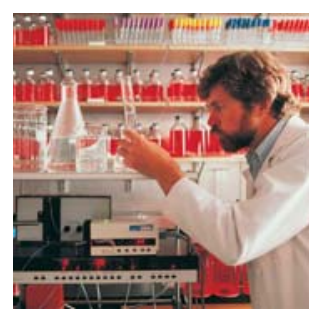

1. 科学者がほかの科学者と実験手法をシェアし、それに手 を加えることのできる新種のウェブサイトのおかげで、 論争が起こっている実験結果やうまく使いこなすのがむ ずかしい実験方法の再現が楽になるかもしれない。

2. 生物学や化学の実験プロトコル（例えばタンパク質の分 離や DNA 断片のスプライシングなどのやり方を順序立 てて記した手順書）は、これまで研究論文や標準プロト コル集といった書物で発表されていた。このような実験 プロトコルに従えば、研究者本人でなくても、特定の実 験をまねて実験結果を確認できるようになる。

3.しかしほとんどの場合、レシピだけでは不十分なことを 科学者は知っている。専門誌は、実験方法の欄を削って 経費を節減しようとしている。そして印刷版のプロトコ ル集では、クローニングで用いられる核移植のように急 激に進歩し、ますます高度化する技術についていけない。

4. おそらくそれよりも重要なのが、手先の器用さや試験管の タイプ、ちょっとした秘訣といった微妙な違いが実験の成 否を分けてしまうということだ。ところが、そのような細か い点は、殴り書きの補足説明だけに記されているか、その 研究室だけの「常識」となっていることが多い。「多くの場合、 プロトコルに科学実験の技は書かれていません。他人に秘 訣は教えないのです。」こう語るのは、スタンフォード大学 (米国カリフォルニア州) で遺伝学を研究する Garry Nolan だ。彼は、自分のプロトコルをオンラインで公開している。

5.このようなウェブサイトは、秘訣をほかの研究者に伝えるう えで役立つかもしれない。このウェブサイトは、ユーザーど うしが互いの投稿内容を編集できるようになっているオンラ イン版百科事典のウィキペディアにほぼ基づいている。既に オンラインで入手できるプロトコルの場合と異なり、このウェ ブサイトは、実験とその実験を実施する際に必要な秘訣を集 めて保管するデータベースを構築し、各ユーザーが自分自身 の秘訣を書き加えていけるようにすることを意図している。

6. このようなウェブサイトの中でも急成長している OpenWetWare は、マサチューセッツ工科大学の学生 によって創設されてから 1 年余りしか経っていない。こ のウィキペディア方式のサイトには、実験方法やその他 の科学的情報資源が寄せられており、5 月現在でのユー

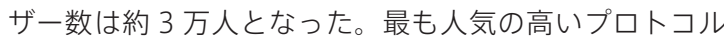
の 1 つは細胞内でのタンパク質産生量を測定する際に用 いられるもので、今ではユーザーが投稿した実験データ
がついており、このプロトコルを使用した場合に予想さ れる展開がわかるようになっている。

7.「この情報はここにしかありません」とOpenWetWare の創設者の 1 人で合成生物学を専攻する大学院生 Sriram Kosuri はいう。このサイトは、生物系のエンジニアリン グ用途の標準ツールを作成しようとする合成生物学の研 究者の間で特に人気が高い。

8. これと競合する 2 つのサイが立ち上げられようとしてい る。1つは、コールド・スプリング・ハーバー研究所出版局 が5月下旬に始動させたサイトで、もう 1 つは Nature の 出版元ネイチャー・パブリッシング・グループが 6 月に立 ち上げる予定のサイトだ。いずれも執筆依頼に基づくプロ トコルが公開され、ユーザーはそれにコメントをつけたり、 書き加えたりすることができる。ウィキペディアとは異な り、コメントについては掲載前に審査され、一部の資料は 購読者のみが利用できる。

9. この方式を支持する人々は、このようなサイトにいくつかの メリットがあるという。すなわち多忙な研究室の責任者が、 そのプロトコルに関する問い合わせに対応する際に手間が 省けるのだ。また、実験方法に関するいくつかの疑問点を 解消することで方法上の欠陷をなくし、場合によっては論争 を引き起こしている実験結果を検証できるようになるかもし れない。さらに、関心が集中する実験結果を引き出す手段 として、目立たない存在にさせられていることの多い実験方 法の注目度を高めるうえでも役立つかもしれない。

10. その反面、実験室の研究者が情報の海で溺れる結果となる 恐れもある。そしてこのようなサイトは、十分な数の科学 者が利用しなければ成功しない。競争の激しい研究分野で は、科学者は自分たちに優位性をもたらすと考えられる実 験方法は公表しないかもしれないのだ。「まず第一に数多 くの分子生物学者が、インターネットに居心地の悪さを感 じているのです」ここう話すのは、OpenWetWare のユー ザーで、ハーバード大学医学系大学院でシステム生物学を 研究する Pamela Silver だ。

11.さらに、文書化されたプロトコルと実験室のベテラン研 究員から仕事を学ぶことに雲泥の差があることは、この ようなサイトの支持者ですら認めている。「最もよい方法 は、実験を行っている研究員のそばに座っていることな のです」っコールド・スプリング・ハーバー研究所出版局の 執行役員 John Inglis は、このように語った。 